\title{
EFFECTS OF DIFFERENT ANTIOXIDANTS ON OXIDATIVE STABILITY OF SOYBEAN OIL IN PET BOTTLES EFEITOS DE DIFERENTES ANTIOXIDANTES NA ESTABILIDADE OXIDATIVA DO ÓLEO DE SOJA EM GARRAFAS PET
}

\author{
Raquel Bonati Moraes Ibsch ${ }^{1}$, Amanda Madruga Bueno ${ }^{1}$, Bruna Regina Warmling ${ }^{1}$, Lisiane \\ Fernandes de Carvalho ${ }^{1}$, Sávio Leandro Bertoli ${ }^{1}$ e Carolina Krebs de Souza ${ }^{1}$ \\ ${ }^{1}$ Universidade de Blumenau, Departamento de Engenharia Química \\ E-mail para contato: rbmoraes@ furb.br
}

\begin{abstract}
Lipid oxidation is responsible for physicochemical and organoleptic changes which reduce not only the food shelf life but also its acceptability. However, this deterioration process can be delayed or prevented by the addition of antioxidants. The aim of this study was to evaluate the effect of different antioxidants, pure and in combination (ascorbyl palmitate, rosemary extract and mix of tocopherols) compared to TBHQ (tert-butylhydroquinone) on oxidative stability index (OSI) of soybean oil stored in PET bottles by Rancimat at $120^{\circ} \mathrm{C}$. The rancimat method is included in the AOCS Cd $12 \mathrm{~b}-92$ standard, due to the ease of use and reproducibility that allows the OSI evaluation in a relatively short period. Therefore, an accelerated shelf life study was performed at $60^{\circ} \mathrm{C}$ for 30 days. The results showed that all evaluated antioxidants and their combinations delayed the lipid oxidation of soybean oil. However, a mix containing ascorbyl palmitate and rosemary extract presented OSI (Oxidative Stability Index) similar to TBHQ. At the end of the 30th day, this referred blend of antioxidants had OSI of 4.83 hours at $120{ }^{\circ} \mathrm{C}$, while treatment with TBHQ showed 5.90 hours at the same temperature. Thus, it was concluded that the evaluated concentration of the ascorbyl palmitate and rosemary extract blend may be an excellent alternative to TBHQ during the maintenance of the soybean oil shelf life in PET bottles.
\end{abstract}

Palavras-chave: Soybean oil. Oxidation. Oil stability. Shelf life. Antioxidants. Oxidative stability index

DOI: $10.5965 / 24473650412018141$

\section{INTRODUÇÃO}

Lipid oxidation, also known as rancidity or autoxidation, is one of the main changes that occurs in fats and oils. It is responsible for modifying their sensorial and nutritional characteristics, besides reducing their shelf life, acceptability and suitability for consumption (SILVA et al., 2017; ALMEIDA, 2016; WALALLAWITAA et al,2016).

Soybean oil is the most consumed edible oil in Brazil due to its high availability and low cost (AMARAL, 2016). However, it is also one of the edible oils most susceptible to the 
lipid oxidation reaction due to the higher degree of unsaturation, characterized by high content of linoleic acid (44\% to 62\%) and $\alpha$-linolenic acid (4\% to $11 \%$ ) (SILVA et al., 2017; BRASIL, 2005a). Although it seems clear polyunsaturated fatty acids (PUFAs) are beneficial to human health being favorable from a nutritional point of view, higher contents of linoleic and linolenic acids result in diminished oxidative stability and shorter shelf life of the oil (SILVA et al., 2017; VILLANUEVA et al., 2017).

Edible oils oxidation is influenced by an energy source such as light, temperature, composition of fatty acids, type of packaging, oxygen, and minor compounds such as metals, pigments, phospholipids, free fatty acids and mono- and diacylglycerols, thermally oxidized compounds. Although lipid oxidation is a spontaneous and irreversible phenomenon, it is possible to delay it by controlling those parameters (CARVALHO et al., 2008; KIM et al., 2007). Among the many methods employed for controlling lipid oxidation, the use of antioxidants is the most effective, convenient and economical means. Food manufacturers world-wide use antioxidants to stabilize food lipids and thus preventing quality deterioration of the products (SHAHIDI; ZHONG, 2010). Thus, in order to delay lipid oxidation, antioxidants have been widely used to maintain the quality and extend shelf life of oils (YANG et al., 2016). The lipid changes in fats and oils, the shelf life of products containing them, as well as their susceptibility to degradations can be evaluated by thermal and oxidative stability analyses. These methods were developed to monitor chemical changes during storage by defining their thermal stability based on the ability to maintain its characteristics during thermal processing. These accelerated oxidative stability tests can be used with the application of heat and gas flows to obtain the data faster and more efficiently (SANTOS et al., 2015). Once oxidative stability of oils and fats is an important parameter for the analysis of their quality, many techniques for oxidation stability characterization have emerged in an attempt to predict shelf life of fats and oils. Mainly because the monitoring of changes in these products under storage conditions is slow and can consume a large amount of reagents (ANTONIASSI, 2001).

One of these techniques is performed using the Rancimat test equipment. It is used to measure the changes in the electrical conductivity in water caused by the formation and release of volatile oxidation compounds. Based on these principles, oil or fat samples are heated under constant air flow at temperature between $100{ }^{\circ} \mathrm{C}$ and $140{ }^{\circ} \mathrm{C}$. These variables cause the dissociation of volatile carboxylic acids, especially formic and acetic acids produced during the oxidation process, which undergo solubilization and consequently increase water conductivity. The response to this conductivity increase is expressed as an oxidation curve that exhibits the induction time, followed by a subsequent shift toward higher oxidation. The interpretation of this curve refers to the number of hours required until the end of the induction time. (SANTOS et al., 2015; MACHADO, 2014; JAIN; SHARMA, 2011).

Therefore, the purpose of this study was to evaluate the oxidative stability of soybean oil added by different antioxidants (Rosemary Extract, Tocopherols Mix and Ascorbyl Palmitate), pure and combined, comparing them to the synthetic antioxidant TBHQ, through Oxidative Stability Index (OSI) at $120^{\circ} \mathrm{C}$ using the Rancimat test equipment. Rosemary Extract and Tocopherols Mix are both natural antioxidants. On the other hand, Ascorbyl palmitate (AP) is a synthetically-derived oil-soluble ester of Ascorbic Acid (AA) is an organic acid occurring widely in the vegetable world. Unfortunately it has very low solubility in pure oils (MARTINEZ et al., 2013; HRAŠ et al., 2000). 


\section{MATERIALS AND METHODS}

\subsection{Materials}

Rosemary Extract, Mix of Tocopherols, Ascorbyl Palmitate and TBHQ were purchased from supplier DuPont Danisco - Nutrition \& Health. Refined, bleached and, deodorized (RBD) soybean oil, already added of $50 \mathrm{mg} / \mathrm{kg}$ of citric acid, was kindly provided by an edible oil refinery company.

\subsection{Experiments}

Antioxidants, combined and pure, were added to soybean oil after refining according to concentrations described at Table 1. Different concentrations of pure antioxidants were defined based on supplier recommendations (minimum dosage to achieve performance) and the limits (maximum dosage) set forth by the current Brazilian legislation (Resolution RDC No. 23 of February 15, 2005). On the other hand, with respect the choice of antioxidant combinations was based on Brazilian legislation for Food Additives (Resolution RDC No. 149 of March, 29, 2017). According to it if an additive is authorized with a maximum numerical limit for the same product in two or more functions, the quantity of the additive to be used in the product may not exceed the maximum limit laid down for this additive among the functions for which it is authorized; and the amount of each additive may not exceed its individual maximum limit.

Samples were homogenized and packed in $900 \mathrm{~mL}$ PET bottles with nitrogen gas $\left(\mathrm{N}_{2}\right)$ added to it. Stability of soybean oil against autoxidation was determined by storing the samples at an elevated temperature $\left(60^{\circ} \mathrm{C} \pm 2{ }^{\circ} \mathrm{C}\right)$ for 30 days, in darkness.

Oxidation level was determined by measuring Oxidative Stability Index (OSI) at $120^{\circ} \mathrm{C}$ at days 0,15 and 30. The equipment used was a Rancimat, Model 743 by Metrohm Pensalab.

Table 1 - Treatments used for soybean oil. Each treatment was stored in darkness condition.

\begin{tabular}{ccc}
\hline Treatments & Antioxidants & $\begin{array}{c}\text { Concentration } \\
(\mathbf{m g} / \mathbf{k g})\end{array}$ \\
\hline 1 (control) & - & No additives \\
\hline 2 & Rosemary Extract (RE) & 150 \\
\hline 3 & Mix of Tocopherols (TO) & 300 \\
\hline 4 & Ascorbyl Palmitate (AP) & 500 \\
\hline 5 & Mix of Tocopherols (TO) + Rosemary Extract (RE) & 350 \\
\hline 6 & Mix of Tocopherols (TO)+ Ascorbyl Palmitate (AP) & 400 \\
\hline 7 & Ascorbyl Palmitate (AP) + Rosemary Extract (RE) & 550 \\
\hline 8 & TBHQ & 70 \\
\hline
\end{tabular}

Source: prepared by the authors (2018). 


\subsection{Procedures for Evaluation of Results}

In order to evaluate the oxidative stability index of soybean oil, the official AOCS method $\mathrm{Cd} 12 \mathrm{~b}-92$ at $120^{\circ} \mathrm{C}$, with air flow of $9 \mathrm{~L} / \mathrm{h}$ was used. The oxidative stability index was expressed in hours. Statistical analysis was performed using analysis of variance (ANOVA) and Tukey's test, at a 5\% level of significance, to compare the means of the results obtained (triplicate).

\section{RESULTS AND DISCUSSION}

The results obtained from oil stability index are shown in Figure 1 and indicate that the addition of $70 \mathrm{mg} / \mathrm{kg}$ of TBHQ has the best antioxidant performance (treatment 7). Treatment 1 (control), with the addition of citric acid alone, presented 4.11 hours for OSI at $120^{\circ} \mathrm{C}$ at the end of the study period, while 7 (70TBHQ) presented 5.90 hours (Table 2).

Exception of treatments 2 (150RE), 3 (300TO), 5 (300TO + 50RE), and 6 (300TO + 100AP), all experiments showed better results of oxidative stability index when compared to control (treatment 1). The lowest results for OSI at $120^{\circ} \mathrm{C}$ at the end of 30 days of storage were obtained in experiments 3 and 2, with 3.73 and 3.77 hours, respectively (Table 2). Both of these treatments showed no significant statistical difference between themselves and their OSI values were also the lowest among all treatments. The low efficiency of antioxidants containing tocopherols (3,5 and 6) is explained in studies carried out by Carvalho et al. (2008), who present ineffective results for inhibition of lipid oxidation of soybean oil, in concentrations of tocopherols higher than that naturally present in edible oils. According to Evans et al. (2002), in general, the antioxidant activity of tocopherols decreases when their concentration exceeds the optimum, and may have a pro-oxidant effect, especially at higher temperatures. Treatment 2 was also not effective in controlling oxidation, suggesting that the combination and/or amount of these antioxidants were not enough.

Treatments 4 (500 AP), 1 (control), $5(350 \mathrm{TO}+\mathrm{RE})$ and $6(400 \mathrm{TO}+\mathrm{AP})$ respectively showed $4.14 ; 4,11 ; 4.09$ and 4.05 hours of OSI at the end of the study (30 days) and did not present a statistically significant difference at the $95 \%$ confidence level (Figure 1b). The oxidative stability index of treatment 8 (with TBHQ) was the highest, with 5.90 hours and presented a statistically significant difference in relation to the other experiments $(p \leq 0.05)$. However, treatment 7 (550 AP + RE), which presented the OSI closest value to experiment 8, at 4.83 hours, has differed statistically from the other assays (1, 2, 3, 4, 5 and 6), showing the highest OSI among them. 
Table 2 - OSI at $120^{\circ} \mathrm{C}$ from soybean oil with 30 days of storage at $60^{\circ} \mathrm{C}$

\begin{tabular}{lccc}
\hline \multirow{2}{*}{ Treatments } & \multicolumn{3}{c}{ OSI (hours at 120 C) } \\
\cline { 2 - 4 } & \multicolumn{3}{c}{ Storage time (days) } \\
\cline { 2 - 4 } (1) Control & $5,10 \pm 0,15^{\mathrm{e}}$ & $4,14 \pm 0,21^{\mathrm{d}}$ & $\mathbf{1 5} 11 \pm 0,06^{\mathrm{c}}$ \\
(2) 150RE & $5,06 \pm 0,13^{\mathrm{e}}$ & $4,04 \pm 0,12^{\mathrm{de}}$ & $3,77 \pm 0,04^{\mathrm{de}}$ \\
(3) 300TO & $5,11 \pm 0,07^{\mathrm{e}}$ & $3,98 \pm 0,04^{\mathrm{de}}$ & $3,73 \pm 0,19^{\mathrm{e}}$ \\
(4) 500AP & $6,57 \pm 0,14^{\mathrm{c}}$ & $4,45 \pm 0,01^{\mathrm{c}}$ & $4,14 \pm 0,28^{\mathrm{c}}$ \\
(5) 300TO+50RE & $5,11 \pm 0,04^{\mathrm{e}}$ & $4,18 \pm 0,01^{\mathrm{d}}$ & $4,09 \pm 0,16^{\mathrm{c}}$ \\
(6) 300TO+100AP & $5,58 \pm 0,06^{\mathrm{d}}$ & $3,92 \pm 0,04^{\mathrm{e}}$ & $4,05 \pm 0,08^{\mathrm{cd}}$ \\
(7) 500AP+50RE $^{\text {(8) }}$ & $7,23 \pm 0,01^{\mathrm{b}}$ & $5,81 \pm 0,16^{\mathrm{b}}$ & $4,83 \pm 0,08^{\mathrm{b}}$ \\
(8) 70TBHQ & $7,43 \pm 0,06^{\mathrm{a}}$ & $6,02 \pm 0,04^{\mathrm{a}}$ & $5,90 \pm 0,16^{\mathrm{a}}$
\end{tabular}

Mean values \pm standard deviation. Mean values in each column followed by different superscript letters presented significant differences $(\mathrm{P}<0.05)$ among treatments.

Source: prepared by the authors (2018).

Figure 1 - Oxidative Stability Index (OSI) at $120^{\circ} \mathrm{C}$ from soybean oil during storage at $60^{\circ} \mathrm{C}$

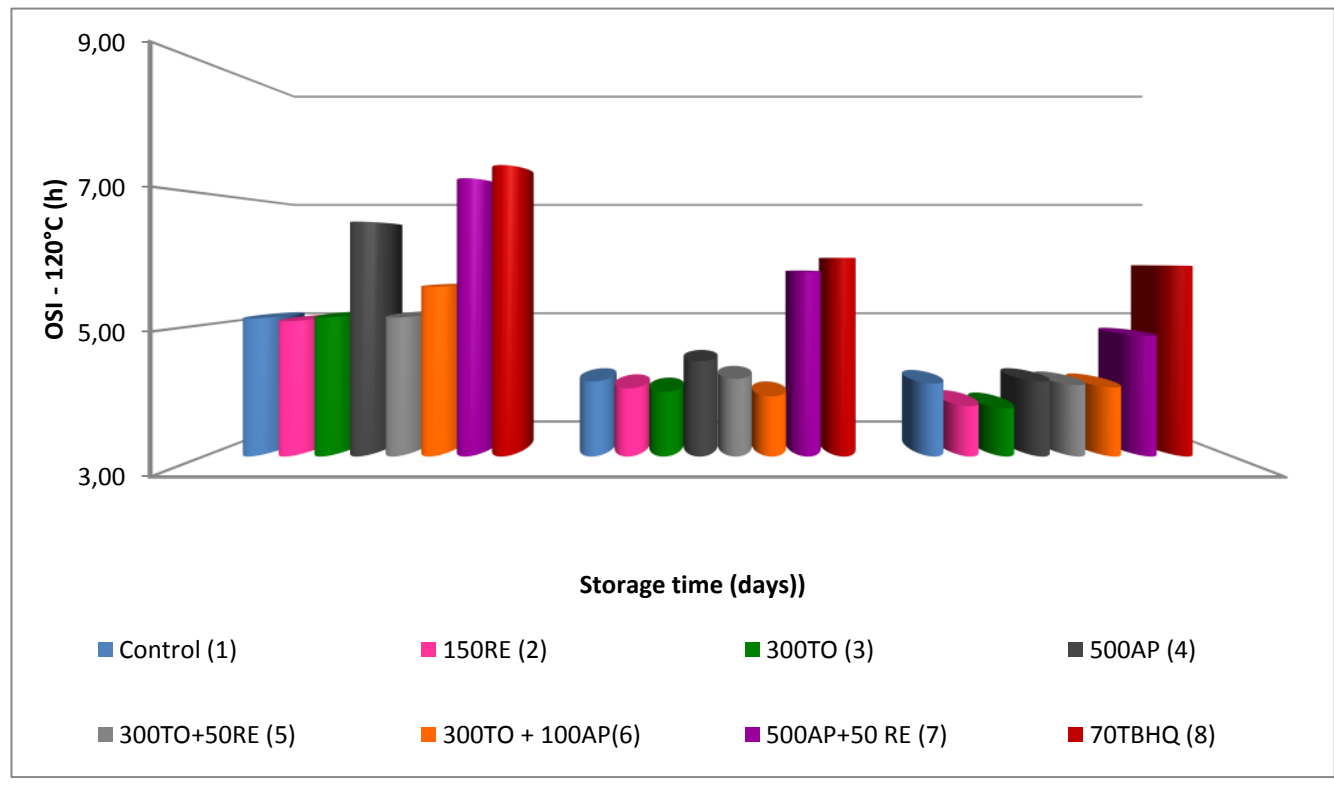

Source: prepared by the authors (2018).

\section{CONCLUSIONS}

It was found that among the seven treatments evaluated and compared to TBHQ (treatment 8), treatment 7 (550 AP + RE) had higher antioxidant activity than the others. This combination of AP and RE can be an excellent alternative to TBHQ, taking into account the increasing market demand for a decrease in the use of that synthetic additive. However, it is 
important to say that AP + RE it is not a combination of exclusively natural antioxidants once AP is a synthetically-derived oil-soluble ester of Ascorbic Acid (AA).

The statistical equivalence was not achieved by now, however from this study is clear that treatment 7 represents the highest potential application for soybean oil shelf extend.

These results supports the importance to continue to expand studies to examine other dosages of AP, combined with RE, also in different temperature ranges, in soybean oil in order to further expand the understanding of this combined antioxidant effects under specific conditions. In the next studies it is important to address other parameters that may interfere with the use of this combination of antioxidants in vegetable oils such as color changes, taste, and stability itself, among others.

\section{ACKNOWLEDGMENTS}

This study was financed in part by the Coordination for the Improvement of Higher Education Personnel (CAPES/Brazil) - Finance code 001.

\section{REFERENCES}

ALMEIDA, L. Estudo cinético da hidrólise em água subcrítica do óleo de soja usado em fritura, 2016, 48 f. Dissertação (Mestrado em Engenharia Química), Departamento de Pós Graduação em Engenharia Química, Universidade Federal Do Paraná, Curitiba, 2016.

AMARAL, D. F. Mercado de óleos vegetais no Brasil (ABIOVE - Associação Brasileira de Óleos e Gorduras). In: SBOG - CONGRESSO DE ÓLEOS E GORDURAS, 2016, Campinas, SP, p. 10, 2016.

ANTONIASSI, R. Métodos de avaliação da estabilidade oxidativa de óleos e gorduras. Boletim do Centro de Pesquisa de Processamento de Alimentos, Curitiba, v. 19, n. 2, p. 353-380, 2001.

BRASIL. Resolução RDC/ANVISA/MS n 270, de 22 setembro de 2005a. Regulamento técnico para óleos vegetais, gorduras vegetais e creme vegetal. Diário Oficial [da] República Federativa do Brasil. Brasília, DF, Seção 1, 23 set. 2005.

BRASIL. Resolução RDC/ANVISA/MS no 23, de 15 de fevereiro de 2005b. Regulamento técnico que aprova o uso de aditivos alimentares, estabelecendo suas funções e seus limites máximos para a categoria de alimentos óleos e gorduras - subcategoria creme vegetal e margarinas.

Disponível

em: http://portal.anvisa.gov.br/documents/33916/388729/Microsoft\%2BWord\%2B\%2BResolu $\% 25 \mathrm{C} 3 \% 25 \mathrm{~A} 7 \% 25 \mathrm{C} 3 \% 25 \mathrm{~A} 3 \mathrm{o} \% 2 \mathrm{BRDC} \% 2 \mathrm{Bn} \% 25 \mathrm{C} 2 \% 25 \mathrm{BA} \% 2 \mathrm{~B} 23 \% 2 \mathrm{Bde} \% 2$ B15\%2Bde\%2Bfevereiro\%2Bde\%2B2005.pdf/f656ac16-30b8-456a-8f93-27f3394f4762. Acesso em: 19 ago 2018.

BRASIL. Resolução RDC/ANVISA/MS n 149, de 29 de março de 2017. Regulamento técnico que autoriza o uso de aditivos alimentares e coadjuvantes de tecnologia em diversas categorias de alimentos e dá outras disposições. Disponível 
emhttp:<http://portal.anvisa.gov.br/documents/10181/2955872/RDC_149_2017_.pdf/96dbaff 2-a705-45bd-8e45-5040f32feb74>. Acesso em: 19 ago 2018.

CARVALHO, S. M.; OGLIARI, P. J; BARRERA-ARELLANO, D.; BLOCK, J. M. Efeito da adição de tocoferóis naturais sobre a qualidade de óleo de soja refinado e embalado em PET durante a estocagem. Brazilian Journal of Food Technology, Campinas, v. 11, n. 2, p. 134$143,2008$.

EVANS J. C.; KODALI, D. R.; ADDIS, P. B. Optimal tocopherol concentrations to inhibit soybean oil oxidation. Journal of American Oil Chemists' Society, Champaign, v. 79, n. 1, p. 47-51, 2002.

HRAŠ, A. R.; HADOLIN, M.; KNEZ, Ž; BAUMAN, D. (2000) Comparison of antioxidative and synergistic effects of rosemary extract with $\alpha$-tocopherol, ascorbyl palmitate and citric acid in sunflower oil. Food chemistry, Norwich, v. 71, n. 2, p. 229-233.

KIM, H. J.; HAHM, T. S.; MIN, D. B. Hydroperoxide as a Prooxidant in the Oxidative Stability of Soybean Oil. Journal of American Oil Chemists' Society, Champaign, v. 84, p. 349-355, 2007.

JAIN, S; SHARMA, M. P. Correlation development for the effect of metal contaminants on the thermal stability of jatropha curcas biodiesel. Energy \& Fuels, Delaware, v. 25, n. 3, p. 1276-1283, 2011.

MACHADO, Y. L. Avaliação da estabilidade oxidativa e determinação da cinética de oxidação de óleos vegetais, ácido oleico e biodiesel utilizando o método PetroOXY (ASTM D7545), 2014, 180 f. Tese (Doutorado em Engenharia Química) - Departamento de Pós-Graduação em Engenharia Química, Universidade Federal do Rio Grande do Norte, Natal, 2014.

MARTÍNEZ, M. I.; PENCI, M.C.; IXTAINA, V.; RIBOTTA, P.D.; MAESTRI, D. Effect of natural and synthetic antioxidants on the oxidative stability of walnut oil under different storage conditions. LWT - Food Science and Technology, Amsterdam, v. 51, p. 44 - 50. 2013.

SHAHIDI, F.; ZHONG, Y. Lipid oxidation and improving the oxidative stability. Chemical Society Reviews, London, v. 39, n. 11, p. 4067-4079, 2010.

SILVA, L. F.; SILVA, M. M. ; RIBEIRO, D. S. Avaliação da estabilidade oxidativa do óleo de soja adicionado de extratos de bagaço de uvas tintas. Revista Brasileira de Agrotecnologia, Garanhuns, v. 7, n. 2, p. 254-259, 2017.

SANTOS, O. V.; EMMERSON, C.; LANNES, S. C. S. Reaction Mechanisms in Thermal Analysis of Amazon Oilseeds. In: TIWARI, A.; RAJ, B. Reactions and mechanisms in thermal analysis of advanced materials. $1^{\text {st }}$ ed. New Jersey: Scrivener Publishing - John Wiley, 2015. Chapter 13, $287-299$. 
WALALLAWITAA, W.K.U.S.; BOPITIYAB, D.; SIVAKANTHANC, S.; JAYAWARDANAD, N.W.I.A.; MADHUJITHE, T. Comparison of oxidative stability of sesame (Sesamum indicum), soybean (Glycine max) and mahua (mee) (Madhuca longifolia) oils against photo-oxidation and autoxidation. Procedia Food Science, Chicago, v. 6, p. 204207, 2016.

VILlANUEVA, E.; RODRÍGUEZ, G.; AGUIRRE, E.; CASTRO, V. Influencia de antioxidantes en la estabilidad oxidativa del aceite de chia (Salvia hispanica L.) por rancimat. Scientia Agropecuaria, Trujillo, v. 8, n. 1, p. 19-27, 2017.

YANG, Y.; SONG, X.; SUI, X.; QI, B.; WANG Z.; LI, Y.; LIANZHOU, J. Rosemary can be used as a synthetic antioxidant to improve vegetable oil oxidative stability. Industrial Crops and Products, Amsterdam, v. 80, p. 141-147, 2016. 